\title{
Von Hartz IV zum Bürgergeld - mehr als ein neuer Name?
}

Die Ampelkoalition plant eine Reform von Hartz IV hin zu einem Bürgergeld. Der Koalitionsvertrag sieht vor, dass es ein Sanktionsmoratorium geben wird, die Regelsätze nicht gesondert erhöht werden, die Anrechnung des Zuverdienstes reduziert wird und der Vermittlungsvorrang abgeschafft wird. Damit würden sich die Bedingungen der Grundsicherung an mehreren Stellen ändern. Die Autor:innen fragen, wie sich diese Veränderungen auf die Arbeitssuche und den Arbeitsmarkt auswirken. Bestehen für Arbeitssuchende noch genug Anreize, eine Arbeit anzunehmen? Welche weiteren Anpassungen sollte es im Zuge der Reform geben?

\section{Aus Hartz IV wird Bürgergeld - nur alter Wein in neuen Schläuchen?}

Maximilian Blömer, Humboldt-Universität zu Berlin; ifo Zentrum für Makroökonomik und Befragungen.

Clemens Fuest, ifo Institut; Ludwig-Maximilians-Universität München.

Andreas Peichl, ifo Zentrum für Makroökonomik und Befragungen; Ludwig-Maximilians-Universität München.

\section{Bürgergeld statt Hartz IV}

Holger Schäfer, Institut der deutschen Wirtschaft Köln e. V., Berlin.

\section{Perspektiven zum Bürgergeld}

Christian Merkl, Alexander-Universität Erlangen-Nürnberg; Institut für Arbeitsmarkt- und Berufsforschung, Nürnberg.

Neuregelung der Hinzuverdienstmöglichkeiten für Transferbeziehende: keine leichte Aufgabe

Kerstin Bruckmeier, Institut für Arbeitsmarkt- und Berufsforschung (IAB), Nürnberg.

Jürgen Wiemers, Institut für Arbeitsmarkt- und Berufsforschung (IAB), Nürnberg.

Bürgergeld und die Zukunft des Sozialstaats

Michael Opielka, ISÖ - Institut für Sozialökologie gGmbH, Siegburg; Ernst-Abbe-Hochschule Jena.

Wolfgang Strengmann-Kuhn, ISÖ - Institut für Sozialökologie gGmbH, Siegburg, und Obmann der Bundestagsfraktion Bündnis 90/Die Grünen im Ausschuss für Arbeit und Soziales.

\section{Beim Übergang zum Bürgergeld mutig große Veränderungen wagen}

Alexander Herzog-Stein, Institut für Makroökonomie und Konjunkturforschung (IMK), Düsseldorf; Universität KoblenzLandau.

Title: From Hartz IV to Citizen's Income ("Bürgergeld") - more than a new name?

Abstract: The new German government coalition is planning a reform of the social welfare programme Hartz IV towards a Citizen's Income. The coalition agreement provides that there will be a moratorium on sanctions on job seekers, that the regular rates of welfare will not be increased separately, that the crediting of additional earnings will be reduced and that the priority for placement in a job will be abolished. This would change the conditions of basic income in several places. The authors ask how these changes will affect job searches and the labour market. Are there still enough incentives for jobseekers to take a job? What other adjustments should there be in the course of the reform? 